\title{
Nephrectomy improves the survival of metastatic renal cell cancer patients with moderate to good performance status - results from a Finnish nation-wide population-based study from 2005 to 2010
}

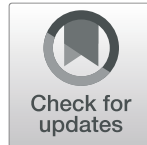

Lauri Laru ${ }^{1,2^{*}}$ (D), Hanna Ronkainen ${ }^{1}$, Pasi Ohtonen ${ }^{3}$ and Markku H. Vaarala ${ }^{1}$

\begin{abstract}
Background: The purpose of this study was to evaluate the effects of cytoreductive nephrectomy (CN) and metastasectomies on the survival of patients with synchronous metastatic renal cell cancer (mRCC) using real-life, population-based national dataset.

Methods: Nationwide data, including all cases of synchronous mRCC in Finland diagnosed on a 6-year timeframe, based on the Finnish Cancer Registry and complemented with patient records from the treating hospitals, were analyzed. Patients with Eastern Cooperative Oncology Group (ECOG) performance status 3-4 were excluded. Univariate and adjusted multivariable survival analysis were performed, including subgroup analysis for patients with different medical therapies. Nephrectomy complications were also analyzed.

Results: A total of 732 patients were included in the analysis. CN was performed for 389 (53.1\%) patients, whereas 68 (9.3\%) patients underwent nephrectomy and metastasectomies of all lesions (surgery with curative intent). Median overall survival (OS) for patients who did not undergo nephrectomy was 5.9 ( $95 \%$ confidence interval [Cl] = 4.6-7.2) months. Patients who had a CN had a median OS of $16.6(95 \% \mathrm{Cl}=14.2-19.1, \mathrm{p}<0.001)$ months, whereas patients who had surgery with curative intent had a median OS of $51.3(95 \% \mathrm{Cl}=36.0-66.6, p<0.001)$ months. The survival benefit of $\mathrm{CN}$ and metastasectomies remained significant in all medical therapy subgroups and in both of the applied multivariable statistical models.
\end{abstract}

Conclusions: Surgical treatment of metastatic renal cell cancer is associated with a significant survival benefit in patients with good and moderate performance status, regardless of the chosen medical therapy.

Keywords: Metastatic renal cell carcinoma, Renal tumor, Population-based, Overall survival, Cytoreductive nephrectomy, Metastasectomy

\footnotetext{
* Correspondence: lauri.tlaru@gmail.com

'Department of Surgery, Medical Research Center Oulu, Oulu University Hospital and University of Oulu, Oulu, Finland

${ }^{2}$ Department of Urology, Oulu University Hospital, PO Box 21, FI-90029 OYS Oulu, Finland

Full list of author information is available at the end of the article
}

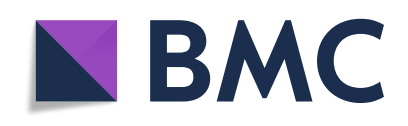

(- The Author(s). 2021 Open Access This article is licensed under a Creative Commons Attribution 4.0 International License, which permits use, sharing, adaptation, distribution and reproduction in any medium or format, as long as you give appropriate credit to the original author(s) and the source, provide a link to the Creative Commons licence, and indicate if changes were made. The images or other third party material in this article are included in the article's Creative Commons licence, unless indicated otherwise in a credit line to the material. If material is not included in the article's Creative Commons licence and your intended use is not permitted by statutory regulation or exceeds the permitted use, you will need to obtain permission directly from the copyright holder. To view a copy of this licence, visit http://creativecommons.org/licenses/by/4.0/. The Creative Commons Public Domain Dedication waiver (http://creativecommons.org/publicdomain/zero/1.0/) applies to the data made available in this article, unless otherwise stated in a credit line to the data. 


\section{Introduction}

The survival benefit of $\mathrm{CN}$ in $\mathrm{mRCC}$ is well established in the era of cytokine-based medical therapy $[1,2]$. Subsequently, contemporary targeted therapy (TT) with tyrosine kinase inhibitor (TKI) and mammalian target of rapamycin (mTOR) inhibitor medications have shown superior results compared to interferon therapy [3-5]. In 2018, Méjean et al. published their landmark prospective clinical trial on the effect of $\mathrm{CN}$, showing noninferiority of sunitinib alone, compared to nephrectomy followed by sunitinib in patients with metastatic renal cell carcinoma who were in the Memorial Sloan Kettering Cancer Centre (MSKCC) intermediate- or poor-risk groups [6]. However, multiple retrospective studies continue to support $\mathrm{CN}$ as a part of the multimodality treatment regimen in metastatic renal cell cancer in the TT era [7-9].

The biological effect of $\mathrm{CN}$ remains somewhat unclear. Several studies support the essential role of immunological mechanisms, such as the primary tumor's ability to induce apoptosis and impairment of crucial signaling pathways of $\mathrm{T}$ lymphocytes $[10,11]$ and production of pro-inflammatory and $\mathrm{T}$ cell inhibitory cytokines and growth factors, promoting metastasis growth [12, 13]. Also, nephrectomy-induced azotaemia and mild metabolic acidosis have been suggested as a possible biological explanation for survival benefit in these patients [14].

As evidence on the matter remains somewhat conflicting, there is a scarcity of tools for clinical decisionmaking considering $\mathrm{CN}$ and metastasectomies. We present a nationwide registry-based dataset of 732 consecutive patients diagnosed with primary mRCC from 2005 to 2010, a 6-year timeframe, which intersects the transition in medical treatment practices from cytokinebased to targeted therapies. Thus, we aimed to objectively evaluate the possible benefits gained by surgical treatment in a real-life, population-based setting.

\section{Materials and methods}

All patients reported with synchronous $\mathrm{mRCC}$ or renal cell carcinoma (RCC) with unknown metastatic status diagnosed between 2005 and 2010 were identified from the Finnish Cancer Registry, which includes all new cancer cases in Finland. Based on these data, patient records of 2169 consecutively diagnosed patients were requested from the treating hospitals. Four hundred and ten cases were diagnosed outside the defined timeframe and thus excluded. Patients without evidence of $\mathrm{mRCC}$ at the time of diagnosis $(n=500)$ or missing treatment or follow-up details ( $\mathrm{n}=166)$ were ruled out, as well as patients under 18 years of age $(n=20)$ and with other cancer of advanced stage $(n=57)$. Thirty-one posthumously diagnosed cases were also excluded. Of the remaining 985 cases, considering the low number of ECOG 3-4 patients among the surgically treated population, and to reflect a more contemporary practice towards cytoreductive surgery for patients with low performance status, we limited the analysis for the ECOG 0-2 patient groups only. A total of 732 patients were included in the final analysis.

The following clinicopathologic variables were collected: sex, age at the time of diagnosis, primary cancer characteristics ( $\mathrm{T}$ stage, Fuhrman grade, and histology), metastasis details (location of metastasis and number of metastatic sites), ECOG performance status, laboratory results (serum hemoglobin and C-reactive protein $[\mathrm{CRP}]$ ) and cause of death. T stage was reassigned according to the 2017 TNM classification [15], and ECOG performance status at time of diagnosis was evaluated retrospectively by the author, if not clearly specified in the patient records.

Treatment protocols and follow-up were at the discretion of the treating physician. All patients received at least one dose of the medications that were considered in the analysis.

\section{Statistical analysis}

The main outcome was OS. Survival time was calculated as the time from diagnosis to death or to the last followup contact. In this analysis, follow-up was limited to 10 years. The survival distribution and median survival were assessed with Kaplan-Meier estimates. Univariate associations between OS and baseline clinical and demographic factors were examined. Comparison of baseline characteristics and risk factors between the treatment subgroups was performed using the $\chi^{2}$ test. Log-rank tests were used to test the influence of baseline factors and treatments on OS. Significance was taken at p < 0.05. Hazard ratios (HRs) with $95 \%$ confidence intervals (95\% CI) for possible significant prognostic factors and treatment options were calculated using univariable Cox regression. Time-dependent multivariable adjusted Cox regression model was used to preclude the immortaltime bias considering treatment options [16, 17]. Due to missing data on some of the risk factors, a multiple imputation technique was used to increase the precision and reduce bias in the analyses. Two different multivariable adjusted Cox models were created. In model 1, we imputed one-by-one all factors, that were found significant $(\mathrm{p}<0.05)$ according to univariate analysis or, had a significant impact on Akaike's Information Criterion, compared to the previous model. In model 2, we only used variables known before the decision of potential surgery. Furthermore, in model 2, a directed acyclic graph (DAG) was created to only include variables needed to get an unbiased adjusted estimate of treatment effect (HR). All analyses were performed using 
IBM SPSS version 27 (Chicago, IL, USA) or SAS version 9.4 (SAS Institute Inc., Cary, NC, USA).

\section{Results \\ Patient characteristics}

A total of 732 patients were included in the analysis, 424 $(57.9 \%)$ were male and $308(42.1 \%)$ were female. Median age was 67.0 years. Mean follow-up was 27.1 (range 0.3$120.0)$ months. Of the $548(74.9 \%)$ patients with available histological diagnosis, $483(88.1 \%)$ had clear cell histology and 80 (11.9\%) had other histology. Sarcomatoid features were found in $47(8.6 \%)$ of these patients. Histological diagnosis was unavailable for 184 (25.1\%) patients. Patients identified with a local tumor stage included: T1, 131 (17.9\%); T2, 109 (14.9\%); T3, 328 (44.8\%); and T4, 118 (16.1\%). Additionally, $\mathrm{T}$ staging was not reliably defined for 46 (6.3\%) patients. A more detailed distribution of baseline characteristics is shown in Table 1.

\section{Prognostic factors}

In the univariate analysis, OS was significantly affected by the following prognostic factors: age, histology (clear cell vs. other), primary tumor T stage, ECOG performance status, number of metastatic sites, local $\mathrm{N}$ stage, distant lymph node metastases, bone metastases, liver, and brain metastases. For biochemical prognostic factors, increased serum CRP and hemoglobin less than the lower limit of normal (LLN) were also identified as statistically significant (Table 2).

There were significant differences in the accumulation of risk factors between the surgical treatment groups. The population in the non-nephrectomy group had a higher median age at the time of diagnosis, compared to the patients with primary tumors that were surgically removed. Also, in the non-surgically treated group, there was a remarkably greater proportion of patients with impaired (ECOG 2) performance status and multiple metastatic sites. However, no significant difference in serum hemoglobin or CRP levels was found between the groups. Nephrectomy was less often performed in patients with T4 tumors, compared to T1-3 tumors (46.6\% vs. $68.7 \%$, respectively; $\mathrm{p}<0.001)$. Patients with T4 tumors were more likely to have anemia $(73.9 \%$ vs. $54.8 \% ; \mathrm{p}=0.001)$, compared to patients with $\mathrm{T} 1-3 \mathrm{tu}-$ mors. Detailed information on the distribution of patient characteristics in different nephrectomy status groups is shown in Table 1.

Effect of nephrectomy and metastasectomies on survival Of all 732 analyzed cases, nephrectomy was performed in $457(62.4 \%)$ patients. In 389 (53.1\%) cases, the operation was cytoreductive, whereas nephrectomy and metastasectomies of all macroscopic metastatic lesions (surgery with curative intent) were performed on 68 (9.3\%) patients. In the cytoreductive nephrectomy group, a concurrent adrenalectomy was performed for 26 of 70 patients with adrenal metastases. The median OS of all patients was 11.9 (10.4-13.3) months. The median OS for patients who underwent nephrectomy was 18.6 (95\% $\mathrm{CI}=15.9-21.2)$ months, which was higher compared to patients who did not undergo nephrectomy (5.9 [95\% CI $=4.6-7.2]$ months, $\mathrm{p}<0.001)$. Patients who had surgery with curative intent had a median OS of 51.3 (95\% CI 36.0-66.6, $\mathrm{P}<0.001$ ) months, whereas patients who had a CN had a median OS of 16.6 (95\% CI 14.2-19.1, P < 0.001 ) months. Kaplan-Meier estimates are shown in Fig. 1.

\section{Nephrectomy in patients receiving medical treatments}

Medical treatments were mainly given after nephrectomy. Of the 349 patients who had both surgery and any medical treatments, 334 (95.7\%) underwent nephrectomy before medication. In the $\mathrm{CN}$ group of 308 patients, surgery took place before medical treatments in $294(95.5 \%)$ cases, and in $40(97.6 \%)$ of 41 cases in the intended curative surgery group, respectively.

In the subgroup of 148 patients who had first-line interferon with or without concurrent chemotherapy as a first-line medical treatment, surgery with curative intent was performed in nine patients. $\mathrm{CN}$ was performed in 93 of these patients and 46 did not undergo nephrectomy. TT as a first-line medical treatment was administered for 314 patients, of whom 32 had surgery with curative intent, 210 underwent $\mathrm{CN}$ and 72 did not undergo nephrectomy. Of the 10 patients who only received cytotoxic chemotherapy as first-line medical treatment, no one was operated with curative intent. CN was performed on five patients and five had no surgical treatment. Kaplan-Meier overall survival estimates for the different combinations of surgical and first-line medical therapy are shown in Table 3.

As some of the patients received both interferon-based treatment with or without cytotoxic chemotherapy (mostly vinblastine) and also targeted therapy at some point of their treatment, the survival data between these groups were compared per nephrectomy status groups. Results are presented in Table 4.

As interferon-based therapy has been replaced by TT, and more recently also with immuno-oncologic therapies, we further analyzed the data excluding patients who received first-line interferon. For this subgroup, baseline patient characteristics and prognostic factors are presented in Supplemental Table 1 and Supplemental Table 2, respectively (see Additional file 1 and Additional file 2 , respectively). In brief, the distribution of baseline characteristics between nephrectomy status groups were similar to Table 1, except for local $\mathrm{T}$ stage, where a 
Table 1 Baseline patient characteristics in different nephrectomy status patient groups

\begin{tabular}{|c|c|c|c|c|c|}
\hline \multirow{3}{*}{ Baseline characteristics } & \multicolumn{4}{|c|}{ Number of patients (\%) } & \multirow[b]{3}{*}{${ }^{1} p$ value } \\
\hline & \multicolumn{3}{|c|}{ Nephrectomy status } & \multirow[b]{2}{*}{ Total $(n=732)$} & \\
\hline & No nephrectomy & Cytoreductive nephrectomy & Surgery with curative intent & & \\
\hline Total & $275(37.6 \%)$ & $389(53.1 \%)$ & $68(9.3 \%)$ & $732(100.0 \%)$ & \\
\hline Gender & & & & & 0.28 \\
\hline Male & $154(56.0 \%)$ & $235(60.4 \%)$ & $35(51.5 \%)$ & $424(57.9 \%)$ & \\
\hline Female & $121(44.0 \%)$ & $154(39.6 \%)$ & $33(48.5 \%)$ & $308(42.1 \%)$ & \\
\hline \multicolumn{6}{|l|}{ Age at diagnosis (years) } \\
\hline Median (25th-75th percentiles) & $73.3(61.9-80.0)$ & $64.0(57.7-72.6)$ & $62.2(57.3-72.1)$ & $67.0(59.6-77.6)$ & $<0.001$ \\
\hline ECOG* & & & & & $<0.001$ \\
\hline 0 & $15(5.5 \%)$ & $41(10.5 \%)$ & $7(10.3 \%)$ & $63(8.6 \%)$ & \\
\hline 1 & $116(42.2 \%)$ & $272(69.9 \%)$ & $50(73.5 \%)$ & $438(59.8 \%)$ & \\
\hline 2 & $144(52.4 \%)$ & $76(19.5 \%)$ & $11(16.2 \%)$ & $231(31.6 \%)$ & \\
\hline T stage* & & & & & 0.063 \\
\hline $\mathrm{T} 1$ & $64(26.6 \%)$ & $57(15.1 \%)$ & $10(14.9 \%)$ & $131(19.1 \%)$ & \\
\hline $\mathrm{T} 2$ & $48(19.9 \%)$ & 49 (13.0\%) & $12(17.9 \%)$ & $109(15.9 \%)$ & \\
\hline T3 & $66(27.4 \%)$ & $227(60.1 \%)$ & $35(52.2 \%)$ & $328(47.8 \%)$ & \\
\hline $\mathrm{T} 4$ & $63(26.1 \%)$ & $45(11.9 \%)$ & $10(14.9 \%)$ & $118(17.2 \%)$ & \\
\hline $\mathrm{N}$ stage & & & & & 0.638 \\
\hline No & $161(58.5 \%)$ & $240(61.7 \%)$ & $39(57.4 \%)$ & $440(60.1 \%)$ & \\
\hline N1 & $114(41.5 \%)$ & $149(38.3 \%)$ & $29(42.6 \%)$ & $292(39.9 \%)$ & \\
\hline Number of metastatic sites & & & & & $<0.001$ \\
\hline 1 & $53(19.3 \%)$ & $114(29.3 \%)$ & $49(72.1 \%)$ & $216(29.5 \%)$ & \\
\hline 2 & $75(27.3 \%)$ & $146(37.5 \%)$ & $16(23.5 \%)$ & 237 (32.4\%) & \\
\hline$\geq 3$ & $147(53.5 \%)$ & $129(33.2 \%)$ & $3(4.4 \%)$ & $279(38.1 \%)$ & \\
\hline \multicolumn{6}{|l|}{ Metastatic sites } \\
\hline Distant lymph nodes & $90(32.7 \%)$ & $99(25.4 \%)$ & $6(8.8 \%)$ & $195(26.6 \%)$ & $<0.001$ \\
\hline Lungs & $192(69.8 \%)$ & $247(63.5 \%)$ & $17(25.0 \%)$ & $456(62.3 \%)$ & $<0.001$ \\
\hline Bone & $96(34.9 \%)$ & $111(28.5 \%)$ & $6(8.8 \%)$ & $213(29.1 \%)$ & 0.001 \\
\hline Adrenal gland & $53(19.3 \%)$ & $70(18.0 \%)$ & $17(25.0 \%)$ & $140(19.1 \%)$ & 0.398 \\
\hline Liver & $75(27.3 \%)$ & $51(13.1 \%)$ & $5(7.4 \%)$ & $131(17.9 \%)$ & $<0.001$ \\
\hline Brain & $24(31.2 \%)$ & $16(18.6 \%)$ & $2(12.5 \%)$ & $42(23.5 \%)$ & 0.093 \\
\hline Histology * & & & & & 0.007 \\
\hline Clear cell carcinoma & $90(79.6 \%)$ & 335 (90.5\%) & $58(89.2 \%)$ & $483(88.1 \%)$ & \\
\hline Other & $23(20.4 \%)$ & $35(9.5 \%)$ & $7(10.8 \%)$ & 65 (11.9\%) & \\
\hline Hemoglobin < LLN* & $132(63.8 \%)$ & 141 (54.0\%) & $28(60.9 \%)$ & 301 (58.6\%) & 0.099 \\
\hline CRP $>$ ULN & 132 (77.6\%) & 154 (72.3\%) & 26 (78.8\%) & 312 (75.0\%) & 0.424 \\
\hline
\end{tabular}

${ }^{1} \mathrm{P}$ value between nephrectomy status groups

*Histological diagnosis was missing for 184 patients, T stage for 46, hemoglobin for 218, and CRP for 316 patients. Percentages were only calculated for the group of patients for whom data on these variables were available

Note: $E C O G$ = Eastern Cooperative Oncology Group, $L L N=$ lower limit of normal, $C R P=C$-reactive protein, $U L N=$ upper limit of normal

statistically significant $(\mathrm{p}<0.001)$ difference was found, unlike in the data with all patients $(\mathrm{p}=0.063)$. According to univariate Cox regression analysis, the statistically significant risk factors for OS remained the same, except for distant lymph node metastases $(\mathrm{p}=0.081$ vs. $\mathrm{p}=$
0.041 in the supplemental analysis vs. in the data with all patients, respectively). Survival analyses are presented in Additional file 3, and Kaplan-Meier estimates are shown in Supplemental Figure 1 (see Additional file 3). As for OS estimates, the observed differences between surgical 
Table 2 Prognostic factors for OS according to univariable Cox model

\begin{tabular}{|c|c|c|}
\hline Prognostic factor & Hazard ratio $(95 \% \mathrm{Cl})$ & $p$ value \\
\hline \multicolumn{3}{|l|}{ Age (years) } \\
\hline$<60$ & 1 (ref) & \\
\hline $60-68$ & $1.01(0.82-1.25)$ & 0.89 \\
\hline $69-77$ & $1.30(1.06-1.59)$ & 0.011 \\
\hline$>78$ & $2.09(1.67-2.61)$ & $<0.001$ \\
\hline \multicolumn{3}{|l|}{ Local tumor stage } \\
\hline $\mathrm{T} 1-3$ & 1 (ref) & \\
\hline $\mathrm{T} 4$ & $1.46(1.19-1.79)$ & $<0.001$ \\
\hline \multicolumn{3}{|l|}{ ECOG } \\
\hline 0 & 1 (ref) & \\
\hline 1 & $1.41(1.06-1.88)$ & 0.018 \\
\hline 2 & $2.94(2.18-3.98)$ & $<0.001$ \\
\hline \multicolumn{3}{|l|}{ Number of metastatic sites } \\
\hline 1 & 1 (ref) & \\
\hline 2 & $1.37(1.13-1.67)$ & 0.001 \\
\hline$\geq 3$ & $1.79(1.49-2.16)$ & $<0.001$ \\
\hline Local lymph node metastases & $1.29(1.10-1.50)$ & 0.001 \\
\hline Distant lymph node metastases & $1.19(1.01-1.41)$ & 0.041 \\
\hline Bone metastases & $1.21(1.03-1.43)$ & 0.021 \\
\hline Liver metastases & $1.52(1.25-1.84)$ & $<0.001$ \\
\hline Brain metastases & $1.84(1.28-2.63)$ & 0.001 \\
\hline Adrenal metastases & $1.06(0.88-1.29)$ & 0.525 \\
\hline Lung metastases & $1.10(0.94-1.29)$ & 0.225 \\
\hline \multicolumn{3}{|l|}{ Histology } \\
\hline Clear cell carcinoma & 1 (ref) & \\
\hline Other & $1.54(1.18-2.00)$ & 0.001 \\
\hline Not available & $2.63(2.20-3.14)$ & $<0.001$ \\
\hline CRP > ULN & $1.44(1.14-1.82)$ & 0.002 \\
\hline Hemoglobin < LLN & $1.50(1.25-1.80)$ & $<0.001$ \\
\hline
\end{tabular}

Note: $\mathrm{Cl}=$ confidence interval, ref $=$ reference group, $E C O G=$ Eastern Cooperative Oncology Group, $C R P=C$-reactive protein, $U L N=$ upper limit of normal, $H b=$ haemoglobin, $L L N=$ lower limit of normal

therapy groups remained statistically significant in the concerned subgroup, as well as in the data with all patients.

\section{Multivariable-adjusted analyses}

To evaluate the independent role of surgery to overall survival, and to eliminate immortality time bias from the estimates, a time-dependent Cox regression analysis was performed, adjusting for the following covariates (model 1): T4 tumor, ECOG, bone metastases, liver and brain metastases, and first-line medical therapy, as these variates were identified as significant prognostic factors in univariate Cox regression analysis (Table 2). To prevent bias due to the significant proportion of cases with no confirmed tumor histology in the non-surgically treated group, we ruled out histology as a covariate. Compared to patients who did not undergo nephrectomy, HR for death was $0.71(95 \% \mathrm{CI}=0.59-0.86, \mathrm{p}<0.001)$ in the $\mathrm{CN}$ group, and $0.27(95 \% \mathrm{CI}=0.19-0.37, \mathrm{p}<0.001)$ in the curatively operated group. Due to some missing values in the data concerning adjusting covariates, a multiple imputation (MI) model was applied to increase the accuracy of the model. In the MI model, HR for death was $0.73(95 \% \mathrm{CI}=0.61-0.87, \mathrm{p}<0.001)$ in the $\mathrm{CN}$ group and $0.26(95 \% \mathrm{CI}=0.19-0.36, \mathrm{p}<0.001)$ months in the curatively operated group.

To further evaluate the relevance of covariates for the multivariable analysis regarding the role of surgical treatment, apart from Cox regression univariate analysis for prognostic risk factors, a DAG was formulated. According to the DAG causal effect identification, age, ECOG, medical therapy, number of metastatic sites, and $\mathrm{T} 4$ tumor were identified as minimal sufficient adjustment sets for estimating the total effect of nephrectomy on OS. A time-dependent Cox regression analysis with the mentioned adjusting covariates was then performed. In this analysis, all relevant data was available for a total of $678(92.6 \%)$ patients; HR for death was $0.72(95 \% \mathrm{CI}=$ $0.59-0.88, \mathrm{p}=0.001)$ in the $\mathrm{CN}$ group and $0.31(95 \% \mathrm{CI}$ $=0.22-0.44, \mathrm{p}<0.001)$ in the intended curative surgery group, compared to the patients who did not have a nephrectomy. In the MI model with the DAG-identified covariates, $\mathrm{HR}$ for death was $0.73(95 \% \mathrm{CI}=0.61-0.88$, $\mathrm{p}<0.001)$ and $0.29(95 \% \mathrm{CI}=0.21-0.40, \mathrm{p}<0.001)$ in the $\mathrm{CN}$ and curatively operated groups, respectively.

\section{Surgical complications/postoperative morbidity and mortality}

Nephrectomy complications at 30-day surveillance according to the revised Clavien-Dindo classification [18, 19] are shown in Table 5. A total 30-day and 90-day complication rates were $18.4 \%$ and $20.4 \%$, respectively. The grade 5 figures represent total postoperative mortality and include all deaths that occurred within the 30day postoperative period, whether or not they seemed to be related to the operation. Data regarding 90-day follow-up complications are shown in Supplemental Table 3 (see Additional file 4).

\section{Discussion}

In this nationwide mRCC population, the median OS for patients who underwent nephrectomy was significantly higher compared to patients who did not undergo nephrectomy (18.6 vs. 5.9 months, respectively). Complete metastasectomy, in addition to radical nephrectomy, resulted in a significantly improved median OS of 51.3 months, compared to both non-surgically treated and $\mathrm{CN}$ groups. This adds to the current evidence 


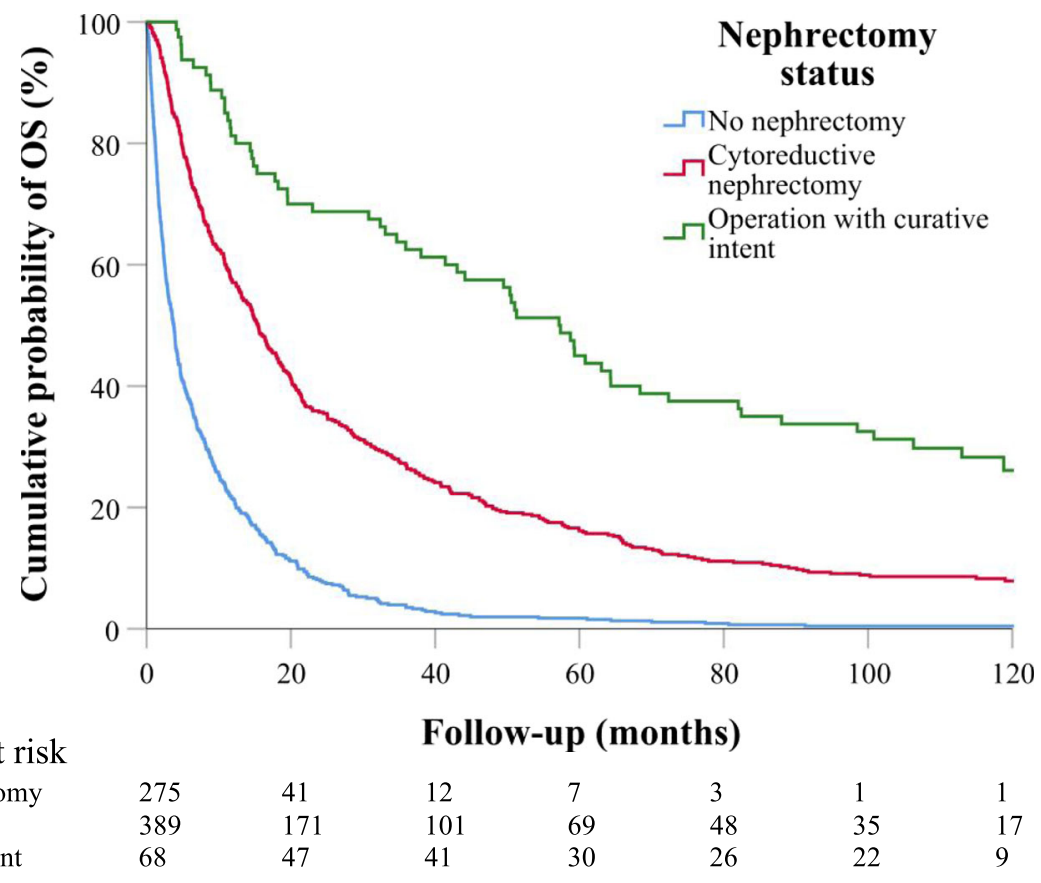

Fig. 1 Kaplan-Meier curves of OS in patient groups with different nephrectomy status

concerning the advantages of metastasectomies in the treatment of mRCC, when all macroscopic tumors are extirpable [20-22]. In the multivariable adjusted analyses, we observed a statistically significant OS benefit gained by both $\mathrm{CN}$ and surgery with a curative purpose. This advantage was distinct in both statistical models with different sets of adjusting covariates. The OS was significantly higher in the $\mathrm{CN}$ group, compared to the non-surgically treated group, in both interferon and TT first-line medical therapy subgroups.

Survival rates in the study population and its subgroups were comparable to other population-based studies. In 2016, De Groot et al. reported a median OS of 17.9 months for patients with primary mRCC treated with $\mathrm{CN}$ and sunitinib, whereas in their study population, patients who received sunitinib but did not undergo $\mathrm{CN}$, the median OS was significantly lower $(8.8$ months) [23]. Correspondingly, a Norwegian populationbased study by Beisland et al. reported a median OS of 10.0 months and 8.0 months for primary mRCC patients diagnosed in 2009-2011 and 2006-2008, respectively [24]. In addition, similar results were shown in a Swedish population-based study, reflecting a median OS of mRCC patients diagnosed 2006-2008 as 12.4 months [25]. In the Danish nationwide DARENCA-2 study population consisting of biopsy-proven $\mathrm{mRCC}$ referred for medical oncologic treatment, the median OS for treated patients increased significantly from 11.5 months in 2006 to 17.2 months in 2010 [26]. These results correlated closely to those reported in our study. However, it must be noted that as our dataset consisted only of patients with primary (synchronous) $\mathrm{mRCC}$, there may be

Table 3 Cross tabulation of survival estimates in different surgical and first-line medical treatment groups

\begin{tabular}{|c|c|c|c|c|c|}
\hline \multirow[b]{2}{*}{ Nephrectomy status } & \multicolumn{2}{|l|}{ First-line medical treatment } & \multirow[b]{2}{*}{ Cytoreductive nephrectomy } & \multirow[b]{2}{*}{$\begin{array}{l}\text { Surgery with } \\
\text { curative intent }\end{array}$} & \multirow[b]{2}{*}{$p$ value } \\
\hline & & No surgical treatment & & & \\
\hline & & \multicolumn{2}{|c|}{ Median OS $(95 \% \mathrm{Cl})$, months } & & \\
\hline & No medical treatment & $3.5(2.5-4.4)$ & $4.1(3.0-5.2)$ & $50.6(0.0-105.7)$ & $<0.001$ \\
\hline & Chemotherapy & $7.3(5.4-9.2)$ & $10.3(3.4-17.3)$ & - & 0.92 \\
\hline & Interferon \pm chemotherapy & $10.0(7.3-12.7)$ & $18.6(14.7-22.4)$ & $43.6(0.0-116.8)$ & 0.002 \\
\hline & Targeted therapy & $10.6(8.1-13.1)$ & $21.9(16.8-27.0)$ & $57.2(36.2-78.1)$ & $<0.001$ \\
\hline
\end{tabular}


Table 4 Survival estimates according to medical therapies and nephrectomy status

\begin{tabular}{|c|c|c|c|c|c|c|}
\hline & Medical treatment & & & & & $p$ value \\
\hline \multirow[t]{4}{*}{ Nephrectomy status } & & $\begin{array}{l}\text { No nephrectomy } \\
\text { (n) }\end{array}$ & $\begin{array}{l}\text { Cytoreductive nephrectomy } \\
\text { (n) }\end{array}$ & $\begin{array}{l}\text { Curative intent } \\
\text { (n) }\end{array}$ & $\begin{array}{l}\text { Overall } \\
\text { (n) }\end{array}$ & \\
\hline & & \multicolumn{5}{|c|}{$\begin{array}{l}\text { Median OS, months (95\% Cl) } \\
\text { (n) }\end{array}$} \\
\hline & Interferon, no TT & $9.5(7.9-11.1)(41)$ & $11.7(5.1-18.3)(51)$ & $17.8(2.1-33.5)(7)$ & $10.4(8.1-12.7)(99)$ & 0.043 \\
\hline & $\Pi \pm$ interferon & $10.8(8.4-13.3)(78)$ & $25.1(20.4-29.8)(253)$ & $58.7(47.3-70.2)(34)$ & $21.3(17.9-24.6)(373)$ & $<0.001$ \\
\hline$p$ value & & 0.15 & 0.004 & 0.296 & $<0.001$ & \\
\hline
\end{tabular}

Note: $O S=$ overall survival, $C l=$ confidence intervals, $\Pi=$ targeted therapy

a tendency towards more aggressive cancers, compared to datasets with both synchronous and metachronous $\operatorname{mRCC}[27,28]$.

The superiority of TT over interferon-based therapy [3-5] was not approved in this cohort, when first-line medical therapies were compared. We detected no significant differences in median survival of patients treated with first-line TT compared to those treated with firstline interferon-based therapy, either in the nonephrectomy population or after $\mathrm{CN}$. However, the survival estimates for $\mathrm{CN}$ patients who received TT only, or in addition to interferon, were significantly higher than for $\mathrm{CN}$ patients who received interferon only. Such differences between OS in the aforementioned medical therapy regimes were not significant for patients who did not undergo nephrectomy or for those who underwent surgery with curative intent, although such trends can be observed, particularly in the latter group.

In our population-based study, more than $95 \%$ of the medically treated patients in the $\mathrm{CN}$ group underwent nephrectomy before medical treatment, and no analysis of the possible advantages or disadvantages of reciprocal sequencing could be made, owing to the limited number of sample cases. The sequencing of $\mathrm{CN}$ and the TKI sunitinib were investigated in a randomized trial by Bex et al. [29], and although no difference in the 28-week progression-free rate was demonstrated, a trend towards higher OS in the deferred $\mathrm{CN}$ arm was shown.
A considerable rate of severe complications occurred in the postoperative period. The complication rates are comparable to previous reports (i.e., Stang et al. reported an intrahospital mortality of $1.4 \%$ patients undergoing nephrectomy for the treatment of renal cancer in Germany in a 2-year period [30]). In a large contemporary cohort of 3644 CN-treated patients with $\mathrm{mRCC}$ from the USA, Palumbo et al. showed an overall complication risk of $39.7-55.3 \%$, stratified according to age groups. Also, an increased risk of in-hospital mortality (3.6\%) for older ( $\geq 71$ years of age) patients was documented, compared to $1.7 \%$ and $1.0 \%$ in the age groups of $56-70$ years and $\leq 55$ years, respectively [31]. Our observed 30-day postoperative mortality was higher than in the recent REMARCC study, which reported 10 (1.3\%) deaths and 45 (6.1\%) high-grade complications from $736 \mathrm{CNs}$ performed in 14 European institutes [32]. In our data, it is noteworthy that 6 of the 19 total grade 5 complications did not occur during the first 30-day postoperative period. Interestingly, one complication included the death of a patient during a prolonged observation period and the complications were not directly related to a certain perioperative surgical complication, but rather due to comorbidities or disease progression. In our study population, only a few operations were made with current mini-invasive approaches, as laparoscopic nephrectomy was not yet widely adopted in Finnish lowervolume hospitals during the studied period. This may

Table 5 Overall rates of complications of 457 nephrectomies in 30-day follow-up

\begin{tabular}{|c|c|c|c|c|c|c|}
\hline \\
\hline \multicolumn{7}{|l|}{$\begin{array}{l}\text { Clavien-Dindo grade } \\
\text { Type of complication }\end{array}$} \\
\hline \multicolumn{7}{|l|}{ Surgical site infection } \\
\hline \multicolumn{7}{|l|}{ Gastrointestinal } \\
\hline Vascular/hemorrhage & - & $5(1.1 \%)$ & $8(1.8 \%)$ & $2(0.4 \%)$ & $3(0.7 \%)$ & $18(3.9 \%)$ \\
\hline \multicolumn{7}{|l|}{ Non-surgical infection } \\
\hline \multicolumn{7}{|l|}{ Comorbidity/disease progression } \\
\hline \multicolumn{7}{|l|}{ Thromboembolic } \\
\hline \multicolumn{7}{|r|}{$3(0.7 \%)$} \\
\hline \multicolumn{7}{|l|}{ Wound dehiscence/hernia } \\
\hline Total & $12(2.6 \%)$ & $24(5.3 \%)$ & $28(6.1 \%)$ & $7(1.5 \%)$ & $13(2.8 \%)$ & $84(18.4 \%)$ \\
\hline
\end{tabular}


contribute to the relatively high rate of postoperative morbidity and mortality, compared to more contemporary datasets [33]. Also, it must be noted that our results may underestimate the incidence of low-grade (ClavienDindo 1-2) complications, for the accuracy in reporting such episodes in patient reports may be incomplete in some institutions.

The strength of this study is that it is based on comprehensive national data from the Finnish Cancer Registry, which receives a notification from the treating hospitals of all suspected cancer cases [34]. To further complement this information, we examined the original patient records from the hospitals and combined these data to make our insight as detailed as possible. However, due to the retrospective and population-based nature of this investigation, all the baseline patient characteristics, such as performance status or laboratory values, could not be retrieved and were therefore not included in the analysis. As a result, patient distributions and analysis, according to the MSKCC or International Metastatic RCC Database Consortium (IMDC), risk groups could not be defined, which can be considered a limitation. Nevertheless, the risk factors for poor OS corresponded to those reported in earlier $\mathrm{mRCC}$ studies [35-40].

\section{Conclusion}

Surgical treatment of $\mathrm{mRCC}$ is associated with a prominent OS benefit in patients with good and moderate performance status. Significant long-term responses can be achieved with total metastasectomy with curative intent, when feasible. $\mathrm{CN}$ was an independent predictor of improved OS in this nationwide database, including patients from both cytokine and TT eras. However, the importance of patient selection cannot be overemphasized, for cytoreductive nephrectomy is associated with relatively high complication rates and postoperative mortality.

\section{Supplementary Information}

The online version contains supplementary material available at https://doi. org/10.1186/s12957-021-02308-0.

\section{Additional file 1: Supplemental Table 1. Baseline patient} characteristics in different nephrectomy status patient groups. 148 patients who received first-line interferon therapy with or without concurrent chemotherapy are not included.

Additional file 2: Supplemental Table 2. Prognostic factors for OS according to univariable Cox model. 148 patients who received first-line interferon therapy with or without concurrent chemotherapy are not included.

Additional file 3: Supplemental Figure 1. Survival analyses for different nephrectomy status groups excluding patients who received first-line interferon. Kaplan-meier curves are shown in Supplemental Figure 1.

Additional file 4: Supplemental Table 3. Overall rates of complications of 457 nephrectomies in 90-day follow-up.

\section{Acknowledgements}

We would like to thank Kaisa Makkonen, M.D. for the assistance on screening and analyzing the patient records. In addition, we would like to thank Ms. Tuula Lähtevänoja, Ms. Katja Vaihoja, and Ms. Leena Heikkilä (Oulu University Hospital, Oulu, Finland) for the acquisition of the patient records.

\section{Authors' contributions}

All authors contributed to the study conception and design. Material preparation and data collection were performed by Lauri Laru and analysis was performed by Lauri Laru, Pasi Ohtonen, and Markku Vaarala. The first draft of the manuscript was written by Lauri Laru and all authors commented on previous versions of the manuscript. All authors read and approved the final manuscript.

\section{Funding}

This work was supported in part by the Finnish Urological Association to Lauri Laru.

\section{Availability of data and materials}

The patient data used in this study are not publicly available to preserve individuals' privacy under the European General Data Protection Regulation.

\section{Declarations}

Ethics approval and consent to participate

The local ethics council of Oulu University Hospital (Oulu, Finland) approved the present study, which was conducted according to the Declaration of Helsinki. Informed written consent from included study patients was not obtained, for the National Institute for Health and Welfare (Helsinki, Finland) approved the present study and the use of registry data following local ethical approval, according to Finnish law. Patient data was anonymized and de-identified prior to statistical analysis.

Consent for publication

Not applicable.

\section{Competing interests}

L.L. declares reimbursements from Sanofi Genzyme/Orion for attending a scientific meeting, outside the submitted work. M.H.V., P.O., and H.R. declare that they have no competing interests.

\section{Author details}

${ }^{1}$ Department of Surgery, Medical Research Center Oulu, Oulu University Hospital and University of Oulu, Oulu, Finland. ${ }^{2}$ Department of Urology, Oulu University Hospital, PO Box 21, Fl-90029 OYS Oulu, Finland. ${ }^{3}$ Division of Operative Care, Oulu University Hospital and Medical Research Center Oulu, University of Oulu, Oulu, Finland.

Received: 26 March 2021 Accepted: 17 June 2021

Published online: 28 June 2021

\section{References}

1. Flanigan RC, Salmon SE, Blumenstein BA, Bearman SI, Roy V, McGrath PC, et al. Nephrectomy followed by interferon alfa-2b compared with interferon alfa-2b alone for metastatic renal-cell cancer. N Engl J Med. 2001;345(23): 1655-9. https://doi.org/10.1056/NEJMoa00301.

2. Mickisch G, Garin A, van Poppel H, de Prijck L, Sylvester R. Radical nephrectomy plus interferon-alfa-based immunotherapy compared with interferon alfa alone in metastatic renal-cell carcinoma: a randomised trial. Lancet. 2001;358(9286):966-70. https://doi.org/10.1016/S0140-6736(01)061 03-7.

3. Motzer RJ, Hutson TE, Tomczak P, Michaelson MD, Bukowski RM, Rixe O, et al. Sunitinib versus interferon alfa in metastatic renal-cell carcinoma. $\mathrm{N}$ Engl J Med. 2007;356(2):115-24. https://doi.org/10.1056/NEJMoa065044.

4. Motzer RJ, Hutson TE, Tomczak P, Michaelson MD, Bukowski RM, Oudard S, et al. Overall survival and updated results for sunitinib compared with interferon alfa in patients with metastatic renal cell carcinoma. J Clin Oncol. 2009;27(22):3584-90. https://doi.org/10.1200/JCO.2008.20.1293.

5. Hudes G, Carducci M, Tomczak P, Dutcher J, Figlin R, Kapoor A, et al. Global ARCC Trial. Temsirolimus, interferon alfa, or both for advanced renal-cell 
carcinoma. N Engl J Med. 2007;356(22):2271-81. https://doi.org/10.1056/ NEJMoa066838.

6. Méjean A, Ravaud A, Thezenas S, Colas S, Beauval J, Bensalah K, et al. Sunitinib alone or after nephrectomy in metastatic renal-cell carcinoma. N Engl J Med. 2018;379(5):417-27. https://doi.org/10.1056/NEJMoa1803675.

7. Bhindi B, Habermann EB, Mason RJ, Costello BA, Pagliaro LC, Thompson RH, et al. Comparative survival following initial cytoreductive nephrectomy versus initial targeted therapy for metastatic renal cell carcinoma. J Urol. 2018;200(3):528-34. https://doi.org/10.1016/j.juro.2018.03.077.

8. Heng DYC, Wells JC, Rini BI, Beuselinck B, Lee J, Knox JJ, et al. Cytoreductive nephrectomy in patients with synchronous metastases from renal cell carcinoma: results from the international metastatic renal cell carcinoma database consortium. Eur Urol. 2014;66(4):704-10. https://doi.org/10.1016/j.eururo.2014.05.034.

9. Graham J, Wells JC, Donskov F, Lee JL, Fraccon A, Pasini F, et al. Cytoreductive nephrectomy in metastatic papillary renal cell carcinoma: results from the international metastatic renal cell carcinoma database consortium. Euro Urol Oncol. 2019;2(6):643-8. https://doi.org/10.1016/j.euo.2019.03.007.

10. Robertson CN, Linehan WM, Pass HI, Gomella LG, Haas GP, Berman A, et al. Preparative cytoreductive surgery in patients with metastatic renal cell carcinoma treated with adoptive immunotherapy with interleukin-2 or interleukin-2 plus lymphokine activated killer cells. J Urol. 1990;144(3):614-7. https://doi.org/10.1016/50022-5347(17)39537-X.

11. Ng CS, Novick AC, Tannenbaum CS, Bukowski RM, Finke JH. Mechanisms of immune evasion by renal cell carcinoma: Tumor-induced T-lymphocyte apoptosis and NFKB suppression. Urology. 2002;59(1):9-14. https://doi.org/1 0.1016/S0090-4295(01)01503-5.

12. Mickisch GH, Mattes RH. Combination of surgery and immunotherapy in metastatic renal cell carcinoma. World J Urol. 2005;23(3):191-5. https://doi. org/10.1007/s00345-004-0468-y.

13. Lahn M, Fisch P, Köhler G, Kunzmann R, Hentrich I, Jesuiter $H$, et al. Proinflammatory and T cell inhibitory cytokines are secreted at high levels in tumor cell cultures of human renal cell carcinoma. Eur Urol. 1999;35(1):7080. https://doi.org/10.1159/000019821.

14. Gatenby RA, Gawlinski ET, Tangen CM, Flanigan RC, Crawford ED. The possible role of postoperative azotemia in enhanced survival of patients with metastatic renal cancer after cytoreductive nephrectomy. Cancer Res. 2002;62(18):5218-22.

15. Amin MB, Edge SB. AJCC cancer staging manual. 8th ed. New York: Springer; 2017. https://doi.org/10.1007/978-3-319-40618-3.

16. Newman NB, Brett CL, Kluwe CA, Patel CG, Attia A, Osmundson EC, et al. Immortal time bias in national cancer database studies. Int J Radiat Oncol Biol Phys. 2020;106(1):5-12. https://doi.org/10.1016/j.jijobp.2019.07.056

17. Agarwal P, Moshier E, Ru M, Ohri N, Ennis R, Rosenzweig K, et al. Immortal time bias in observational studies of time-to-event outcomes. Cancer Control. 2018; 25(1):1073274818789355. https:/doi.org/10.1177/1073274818789355.

18. Clavien PA, Sanabria JR, Strasberg SM. Proposed classification of complications of surgery with examples of utility in cholecystectomy. Surgery. 1992;111(5):518-26.

19. Dindo D, Demartines N, Clavien P. Classification of surgical complications: A new proposal with evaluation in a cohort of 6336 patients and results of a survey. Ann Surg. 2004;240(2):205-13. https://doi.org/10.1097/01.sla.0000133 083.54934.ae.

20. Lyon TD, Thompson RH, Shah PH, Lohse CM, Boorjian SA, Costello BA, et al. Complete surgical metastasectomy of renal cell carcinoma in the post-cytokine era. J Urol. 2020;203(2):275-82. https://doi.org/10.1097/JU.0000000000000488.

21. Beetz O, Söffker R, Cammann S, Oldhafer F, Vondran FWR, Imkamp F, et al. Extended hepatic metastasectomy for renal cell carcinoma-new aspects in times of targeted therapy: a single-center experience over three decades. Langenbeck's Arch Surg. 2020;405(1):97-106. https://doi.org/10.1007/s00423019-01852-4.

22. Sponholz S, Schirren M, Oguzhan S, Mese M, Schirren J. Long-term outcome after resection of isolated thoracic lymph node metastases of renal cell cancer. Ann Thorac Surg. 2020;109(1):262-9. https://doi.org/10.1016/j.athora csur.2019.07.054.

23. de Groot S, Redekop WK, Sleijfer S, Oosterwijk E, Bex A, Kiemeney LALM, et al. Survival in patients with primary metastatic renal cell carcinoma treated with sunitinib with or without previous cytoreductive nephrectomy: results from a population-based registry. Urology. 2016;95:121-7. https://doi. org/10.1016/j.urology.2016.04.042

24. Beisland C, Johannesen TB, Klepp O, Axcrona U, Torgersen KM, Kowalski J, et al. Overall survival in renal cell carcinoma after introduction of targeted therapies: a norwegian population-based study. Onco Targets Ther. 2017;10: 371-85. https://doi.org/10.2147/OTT.S123061.

25. Wahlgren T, Harmenberg U, Sandström P, Lundstam S, Kowalski J, Jakobsson $\mathrm{M}$, et al. Treatment and overall survival in renal cell carcinoma: a Swedish population-based study (2000-2008). Br J Cancer. 2013;108(7): 1541-9. https://doi.org/10.1038/bjc.2013.119.

26. Soerensen AV, Donskov F, Hermann GG, Jensen NV, Petersen A, Spliid H, et al. Improved overall survival after implementation of targeted therapy for patients with metastatic renal cell carcinoma: Results from the danish renal cancer group (DARENCA) study-2. Eur J Cancer. 2013;50(3):553-62. https:// doi.org/10.1016/i.ejca.2013.10.010.

27. Kim SH, Lee D, Park B, Joo J, Joung JY, Seo HK, et al. Survival of patients receiving systematic therapy for metachronous or synchronous metastatic renal cell carcinoma: a retrospective analysis. BMC Cancer. 2019;19(1):688. https://doi.org/10.1186/s12885-019-5900-1.

28. Kammerer-Jacquet S, Brunot A, Pladys A, Bouzille G, Dagher J, Medane S, et al. Synchronous metastatic clear-cell renal cell carcinoma: a distinct morphologic, immunohistochemical, and molecular phenotype. Clin Genitourin Cancer. 2017;15(1):e1-7. https://doi.org/10.1016/j.clgc.2016.06.007.

29. Bex A, Mulders PFA, Jewett M, Wagstaff J, van Thienen JV, Blank CU, et al. Comparison of immediate vs deferred cytoreductive nephrectomy in patients with synchronous metastatic renal cell carcinoma receiving sunitinib the SURTIME randomized clinical trial. JAMA Oncol. 2019;5(2):16470. https://doi.org/10.1001/jamaoncol.2018.5543.

30. Stang A, Büchel C. Renal surgery for kidney cancer in Germany 2005-2006: Length of stay, risk of postoperative complications and in-hospital death. BMC Urol. 2014;14(1):74. https://doi.org/10.1186/1471-2490-14-74.

31. Palumbo C, Knipper S, Dzyuba-Negrean C, Pecoraro A, Rosiello G, Tian Z, et al. Complication rates, failure to rescue and in-hospital mortality after cytoreductive nephrectomy in the older patients. J Geriatr Oncol. 2019;11(4): 718-23. https://doi.org/10.1016/j.jgo.2019.06.005.

32. Roussel E, Campi R, Larcher A, Verbiest A, Antonelli A, Palumbo C, et al. Rates and predictors of perioperative complications in cytoreductive nephrectomy: analysis of the registry for metastatic renal cell carcinoma. Eur Urol Oncol. 2020;3(4):523-9. https://doi.org/10.1016/j.euo.2020.04.006.

33. Xu H, Ding $\mathrm{Q}$, Jiang H. Fewer complications after laparoscopic nephrectomy as compared to the open procedure with the modified clavien classification system - a retrospective analysis from southern china. World J Surg Oncol. 2014;12(1):242. https://doi.org/10.1186/1477-7819-12-242.

34. Teppo L, Pukkala E, Lehtonen M. Data quality and quality control of a population-based cancer registry: Experience in Finland. Acta Oncol. 1994; 33(4):365-9. https://doi.org/10.3109/02841869409098430.

35. Oake JD, Patel P, Lavallée LT, Lattouf J, Saarela O, Klotz L, et al. Outcomes and prognosticators of stage 4 renal cell carcinoma with pathological T4 primary lesion using a large, Canadian, multi-institutional database. Can Urol Assoc J. 2020;14(2):24-30. https://doi.org/10.5489/cuaj.5941.

36. Borregales LD, Kim DY, Staller AL, Qiao W, Thomas AZ, Adibi M, et al. Prognosticators and outcomes of patients with renal cell carcinoma and adjacent organ invasion treated with radical nephrectomy. Urol Oncol. 2016; 34(5):237.e19-26. https://doi.org/10.1016/j.urolonc.2015.11.020.

37. Motzer RJ, Bukowski RM, Figlin RA, Hutson TE, Michaelson MD, Kim ST, et al. Prognostic nomogram for sunitinib in patients with metastatic renal cell carcinoma. Cancer. 2008;113(7):1552-8. https://doi.org/10.1002/cncr.23776.

38. Shuch B, La Rochelle JC, Wu J, Klatte T, Riggs SB, Kabbinavar F, et al. Performance status and cytoreductive nephrectomy: redefining management in patients with poor performance. Cancer. 2008;113(6):132431. https://doi.org/10.1002/cncr.23708.

39. Claeys T, Lumen N, Kumps C, Praet M, De Meerleer G, Rottey S, et al. The independent oncological role for cytoreductive nephrectomy in metastatic renal cell carcinoma: Prognostic features in the era of targeted therapies. Urol Oncol. 2017:35(4):152.e13-22. https://doi.org/10.1016/j.urolonc.2016.10.013.

40. Heng DY, Xie W, Regan MM, Harshman LC, Bjarnason GA, Vaishampayan UN, et al. External validation and comparison with other models of the international metastatic renal-cell carcinoma database consortium prognostic model: A population-based study. Lancet Oncol. 2013;14(2):1418. https://doi.org/10.1016/S1470-2045(12)70559-4.

\section{Publisher's Note}

Springer Nature remains neutral with regard to jurisdictional claims in published maps and institutional affiliations. 